Article

\title{
Expansion of Policy Domain of Sustainable Consumption and Production (SCP): Challenges and Opportunities for Policy Design
}

\author{
Yasuhiko Hotta ${ }^{1, *}$, Tomohiro Tasaki ${ }^{2}$ (D) and Ryu Koide ${ }^{1,2}$ (D) \\ 1 Sustainable Consumption and Production Area, Institute for Global Environmental Strategies, \\ Kamiyamaguchi 2108-11, Hayama 240-0115, Kanagawa, Japan; koide.ryu@nies.go.jp \\ 2 Material Cycles Division, National Institute of Environmental Studies, Japan, 16-2, Onogawa, \\ Tsukuba 305-8506, Ibaraki, Japan; tasaki.tomohiro@nies.go.jp \\ * Correspondence: hotta@iges.or.jp
}

check for updates

Citation: Hotta, Y.; Tasaki, T.;

Koide, R. Expansion of Policy

Domain of Sustainable Consumption and Production (SCP): Challenges and Opportunities for Policy Design. Sustainability 2021, 13, 6763.

https://doi.org/10.3390/su13126763

Academic Editor: Paulo Peças

Received: 15 April 2021

Accepted: 11 June 2021

Published: 15 June 2021

Publisher's Note: MDPI stays neutral with regard to jurisdictional claims in published maps and institutional affiliations.

Copyright: (c) 2021 by the authors. Licensee MDPI, Basel, Switzerland. This article is an open access article distributed under the terms and conditions of the Creative Commons Attribution (CC BY) license (https:// creativecommons.org/licenses/by/ $4.0 /)$.

\begin{abstract}
Since 2015, the international policy community has started to agree on international agreements with ambitious middle-term and long-term goals, highly relevant to sustainable consumption and production (SCP) such as those seen in the Paris Agreement, SDGs, and the plastic-related agreements at the G7 and G20 processes. Along with this trend, there has been growing attention given to socio-technical system change or "transition". Policy debate is putting more focus on the need to change consumption and production patterns and deal with various ecological consequences within planetary boundaries such as decarbonization, absolute reduction in material throughput, or creation of a plastic-free society. This paper examines the expansion of the policy domain of SCP in three phases; SCP focusing on pollution control and cleaner production (SCP 1.0), SCP from the perspective of product lifecycle (SCP 2.0), and SCP focusing on systematic changes in socio-technical systems driving consumption and production (SCP 3.0). The potential impact of a wider SCP policy domain can be comparable to the historical shift in discourse related to ecological modernization theory from pollution prevention to efficiency. This emerging trend corresponds to the need for a fresh approach to policy design which can facilitate transition to sustainability.
\end{abstract}

Keywords: sustainable consumption and production; sufficiency; efficiency; transition; discourse analysis; policy design

\section{Introduction}

One of the key policy concepts on the global sustainability agenda since the 1990s has been sustainable consumption and production (SCP). This was triggered by economic globalization and the increasing distance between where goods are produced and where they are consumed [1]. SCP was a key component of Agenda 21, the action plan adopted at the UN Conference on Environment and Development (Rio Summit) in 1992 [2]. Then, at the United Nations Conference on Sustainable Development in 2012 (Rio+20), the UN 10 Years Framework Programme of Sustainable Consumption and Production (10YFP) was adopted, and in 2015, SCP became one of the 17 Sustainable Development Goals (SDGs). In a report published in 2015, the United Nations Environment Programme (UNEP) defined SCP as "a holistic approach to minimizing the negative environmental impacts from consumption and production systems while promoting quality of life for all" [3]. However, the focus of SCP has widened over the last few years due to a shift in emphasis of environmental policy and sustainability agenda.

Since 2015 in particular, several important international agreements with strong links to SCP have been adopted including the Paris Agreement, and the 2030 Agenda on Sustainable Development (SDGs). Furthermore, agreements on marine plastic issues emerged from the G20 and G7 processes, including the G20 Osaka Blue Ocean Vision and the Ocean 
Plastic Charter launched by Canada and agreed in 2018 by EU, UK, France, Italy, Germany and Canada. Although these international agreements are based on voluntary efforts, they have some common features in terms of setting very ambitious and unprecedented middleterm and long-term goals. These goals include decarbonization or achieving a net zero society, elimination of marine plastic discharge, and reviewing lifestyles and economies within planetary boundaries, which are central to our economy, which depends on material and energy consumption and production. To achieve these goals, we must make fundamental changes to our social and economic structures including business models and lifestyles.

However, $\mathrm{SCP}$ as a policy concept is often used in an intermixed and confused manner due to existence of the different versions as described in this paper. This occurs because the scope of SCP policy has been expanded over years. For example, SCP policies can target individual industrial processes, products and services, or the entire system and subsystems. Systemic solution and individual solution respectively call for different policy instruments and discussion. To make a policy process effective, it is necessary to summarize these different versions of SCP and facilitate the policy discussions on sustainability transition. The objective of this paper is therefore to summarize the different policy backgrounds on how SCP as a policy domain evolved from SCP 1.0 to SCP 2.0 and then onto the recent interest over sustainability transition (SCP 3.0) by applying environmental policy discourse analysis. In this way, we will characterize the emerging trend of SCP that has developed along with very ambitious and unprecedented middle-term and long-term goals for sustainability such as a net zero society, elimination of marine plastic discharge, and lifestyles and economies within planetary boundaries. The paper posits that a new approach for policy design is required to tackle emerging opportunities and challenges caused by this recent trend (SCP 3.0).

In this paper, we look at how the focus of SCP policy has shifted and widened over the last 30 years, and pay particular attention to the development of SCP policy discourse. Our main methodology is an analysis of environmental policy discourse, recognizing that framing, interpretation, and generation of storylines play key roles in the politics of sustainability. We summarize and describe this shift in three phases-SCP 1.0 to SCP 3.0. Building on ecological modernization theory, this paper provides a streamlined narrative on how the SCP-related policy domain first expanded from pollution prevention and cleaner production (SCP 1.0) to increasing efficiency throughout of life-cycle of materials, products, and services (SCP 2.0). Then, in the late 2000s, policy discussions on the SCP-related domain expanded to include the systematic transition of socio-technical systems, lifestyles, and infrastructure driving consumption and production (SCP 3.0). This expansion can be observed in the recent international policy agendas of sustainability such as the Paris Agreement, and agreements emerging from the G7 and G20 processes. Finally, the paper argues that the long-term and middle-term sustainability goals in SCP 3.0 require a futureoriented policy design going beyond conventional evidence-based policymaking.

\section{Methodology: Environmental Policy Discourse Analysis}

In our streamlined narrative for SCP policy discourse development, we highlight the emergence of a new version of $\mathrm{SCP}$ which requires a fresh approach to policy design. Policy debate on sustainability is strongly linked to framing, interpretation, and generation of storylines. As Fairhead and Leach point out in their political studies of science with regard to deforestation [4], it is the framing and interpretation of issues on a global level that guides policy and strategy on national and local levels of politics and science.

Environmental sustainability encompasses not just physical issues related to deteriorating environmental quality surrounding human settlements, but also includes a complex set of scientific data, interpretation of this data into political and social implications, and then the distribution of values based on that interpretation. Thus, as Hajer [5], Litfin [6] and Dryzek [7] have stated, the persuasiveness of the story or discourse is important for effective consensus building and policymaking. The storyline or narrative should assist 
the scientist, environmentalist, or politician, to show how their work fits into the whole picture of social and environmental issues [5,7].

For example, Hajer argues that "(e)nvironmental politics is only partially a matter of whether or not to act, it has increasingly become a conflict of interpretation in which a complex set of actors can be seen to participate in a debate in which the terms of environmental discourse are set" [5]. In a similar way, Litfin argues in her study of the international negotiations over ozone layer protection that "(e)nvironmental policy is heavily dependent on such cognitive factors as scientific knowledge, philosophical ideas, and public opinion" [6]. This kind of discursive approach appears to focus only on conceptual, philosophical and symbolic levels of conflict. However, framing certain issues within climate change, decarbonization or building a circular economy has political, social and economic implications for the daily routines of every single sector in a modern industrialized society [8]. For example, by framing an individual citizen in the context of climate change or waste problems, we transform them into a major consumer of energy and a source of greenhouse gas emissions. Similarly, a household would be transformed into a source of waste as well as a processing site for waste separation and recycling. A farming family who cultivate rice paddies in Southeast Asia, if framed in a certain context, would be transformed into a source of methane gas emissions. This type of framing and interpretation of issues brings about a change in attitude for governments, think-tanks, the academic community, industry, and NGOs so that they then take particular policies and strategies [4].

Sustainability issues provoke a process of re-framing and reconsidering of various "structured" daily activities that are part of a modern socio-technical system. However, we must question the values and worldviews behind how environmental issues are understood and interpreted. Otherwise, as Lipschutz and Conca argue, we would end up simply reproducing rather than restructuring (in the sense of transforming and altering or transition) the modern socio-technical system [9].

It is also important to remember that although proper interpretation of the issues is important for policy debate on environmental sustainability, it does not mean that one particular interpretation or a specific application of scientific knowledge is based on a clear-cut political position. When mediating between conflicting positions, environmental discourse can be used to construct coalitions. These coalitions can be merged to contextualize certain political positions in the politics of sustainability rather than the collective activities of individual actors [5]. Furthermore, discourse is not always consistent. In addition, indeed, even vagueness and contradiction are important elements of policy discourse on sustainability when trying to mediate between conflicting positions. Hajer calls this aspect of policymaking 'discursive closure'. This means that the interpretation and definition of a certain problem can set the target for policymaking (it is also important to see where the focus of the problem lies and what is left out) [5].

The power of discourse for framing, interpretation, and generation of certain storylines is important to provoke and continue sustainable transition as a way to transform sociotechnical systems. Ganz argues that, when looking to provoke societal change, generating a storyline can be a key instrument for relating, motivating, renewing motivation, and sustaining collaborative actions among stakeholders [10].

Thus, this paper uses environmental policy discourse analysis to demonstrate the changing emphasis in SCP policy domains by reviewing research papers relevant to SCP policy, sustainable lifestyles and sustainability transition. We also reviewed policy reports and outcome documents of international processes relevant to SCP policy domains, especially those of the UN (especially UNEP), G7, and G20.

\section{Three-Phase Development of SCP Policy Domain}

Environmental policy and business strategies have gradually shifted their focus from pollution prevention and cleaner production, through lifecycle-based efficiency, to the systematic change of socio-technical systems. Based on environmental policy discourse analysis $[5,7]$, this section will provide a streamlined narrative of how the SCP policy 
domain has expanded over the past few decades, using phases which we call SCP 1.0, SCP 2.0, and SCP 3.0 .

\subsection{SCP 1.0: Pollution Prevention and Cleaner Production}

The rise of the first phase of SCP, or SCP 1.0, corresponded with the need to prevent environmental pollution resulting from rapid industrialization in developed economies in the 1960s and 1970s. There was also a need for more energy-efficient and cleaner production in response to the energy crisis of the 1970s.

SCP 1.0 typically emerged in Japan with the development of policies and industrial initiatives on pollution prevention and cleaner production. Indeed, theorists and advocates of ecological modernization initiatives agree that Japan's experience in pollution prevention in the 1970s was a model case that successfully implemented environmental policy in harmony with economic competitiveness [5,7,11-13]. Industrial pollution became the focus of environmental issues, and from the late 1960s to the early 1970s, Japan enacted strong environmental regulation. Rapid urbanization and motorization resulted in worsening urban air pollution due to an increase in automobile use in the 1970s. At the same time, as Jänicke and Weidner point out, the energy crisis also prompted a restructuring of production systems [11]. The Japanese government promoted structural changes in Japanese industry in response to the oil crisis. According to Mitsuhashi, business investment for this restructuring was supported by strong governmental regulations as well as low-interest loans from governmental financial bodies [14].

This governmental-oriented restructuring of Japan's production system in the 1970s contributed to savings in both energy and resources. These cost-cutting measures in production were a response to the energy crisis, but they contributed to the subsequent improvements in environmental technology. Japan's industrial sector was almost fully dependent on imported oil as an energy source, so the energy crisis resulted in a shift from an economy depending on heavy and chemical industries with high-energy consumption to an economy dependent on assembly-based industries such as car and electronic manufacturing. This also helped Japanese industry make the transition to a cleaner production system.

As Nakanishi suggested, changes in manufacturing processes due to energy-saving, technological innovation and industrial restructuring, brought about greater reductions in environmental pollution than the end-of-pipe measures stemming directly from strict environmental regulations [15]. For example, wastewater pollution (COD; chemical oxygen demand) from the pulp industry was reduced by $84 \%$ using in-process technology. Water treatment using end-of-pipe technology only contributed to $16 \%$ reduction in pollution. Therefore, a shift in the production process motivated by efficient production results in less environmental pollution than end-of-pipe treatment technology. Nakanishi argues that changes in resources and materials used in final products also served to cut costs, as well as protect the environment [15]. Thus, it is highlighted that initial strong environmental regulation not only motivated the installation of end-of-pipe technologies, but also triggered energy-saving, technological innovation and industrial restructuring, resulting in better environmental and economic performance.

A similar argument can be seen in the justification of cleaner production $(\mathrm{CP})$ as an environmental measurement promoted by UNEP. As an industrial and technological concept for pollution prevention, the history of CP goes back to the 1970s and emphasizes the efficient use of resources while minimizing waste and pollution. Thus, $\mathrm{CP}$ can be used to achieve a sustainable society through efficient production processes in industry and distinguishes itself from simply promoting the 'end-of-pipe' approach. In this respect, CP tends to focus on the re-engineering of production processes and the international transfer of environmental technology. In 1989, UNEP launched the Cleaner Production Program under the UNEP Industry and Environment (now UNEP DTIE) section in Paris. Then, in 1992, under Agenda 21 [2], "Promoting cleaner production" (Chapter 30 of Agenda 21) became one way to "strengthen the role of business and industry(Chapter 30 of Agenda 21)" 
in activities for sustainable development. Thus, throughout 1990s, CP became one of the most important principles underpinning the relationship between environment and industry in the UN system. Another major UN organization aside from UNEP promoting cleaner production was the United Nations Industrial Development Organization (UNIDO) (especially the establishment of National Cleaner Production Centers).

Notably, CP was presented as a "win-win strategy". According to UNEP, " ... [CP] protects the environment, the consumer and the worker while improving industrial efficiency, profitability, and competitiveness" [16]. In this sense, UNEP understands CP as a development strategy in its own right [17]. Discussions on CP should focus on the need for industry and business to make changes in their production and service processes to achieve sustainable development. UNEP argues that more efficient production processes and services through the application of environmental technology and appropriate financial mechanisms will contribute to pollution prevention [18]. In a similar way, UNIDO emphasizes that "(Cleaner Production) refers to the approach (the mindset and way of thinking) of how goods and services are produced with the minimum environmental impact within present technological and economic limits. Cleaner Production does not deny economic and industrial growth, but it insists that growth be ecologically sustainable" [19].

$\mathrm{CP}$ also takes pollution prevention strategies that have achieved success in industrialized society and applies them to developing countries. In fact, UNIDO and UNEP cooperated to establish national CP centers mainly in developing countries. CP working groups were formed and created a network to accumulate academic knowledge on specific technology and engineering issues. UNEP is also working to set up financial mechanisms promoting cleaner production projects in developing countries.

As UNEP indicates [3], CP is a starting point for SCP policy development focusing more on technology and engineering, as well as on the management side of sustainability. This means that CP serves to mainstream pollution prevention as one way to achieve sustainability. At the same time, CP was a prelude to SCP 2.0, as described below. UNEP also emphasizes that focus of $\mathrm{CP}$ has shifted over the years from "single-issue, reactive, site-specific and end-of-pipe" to a "systems approach", and from "production-oriented" to "life-cycle" orientation [20]. CP is increasingly linked to resource and energy efficiency [3]. Also, the concept of SCP and policy emerged out of CP. For example, UNEP and UNIDO established a regional network of CP centers originally called Roundtables on Cleaner Production and Sustainable Consumption. These networks later developed into Regional Roundtables on SCP, including those for Africa and the Asia-Pacific.

\subsection{SCP 2.0: Lifecycles}

The SCP policy domain expanded from pollution prevention and CP in the 1970s and 1980s, to efficiency of the product lifecycle in the 1990s, as indicated in Table 1. As discussed in the previous section, UNEP's development of CP also shifted from SCP 1.0 to SCP 2.0. The 1980s and 1990s saw the emergence of global environmental challenges such as climate change, loss of biodiversity, destruction of rainforest, as well as waste issues and food safety, stemming from globalization, mass production, mass consumption and improper waste management. Thus, we could observe the co-evolution of SCP2.0 (with its focus on product lifecycles) with the globalization of production and distribution. With the globalization of production and consumption, environmental policy put less focus on direct and site-specific issues and began to target indirect and lifecycle-based ones such as GHGs, resource depletion, and waste. Environmental impacts associated with trade and the globalized production system provoked more awareness on the importance of footprint indicators [21-23] for better understanding of indirect environmental and material costs.

Ecological modernization theory $[5,7,13,24-26]$ states that there was a significant shift in the discourse of policymaking and corporate strategy on the environment and industry from the 1970s to 1990s, mainly in advanced industrialized societies $[5,7,27,28]$. The theory claims that industrialization can be achieved in harmony with environmental conservation with no economic disadvantages. In other words, the relationship between environmental 
protection and economic competitiveness has been reconfigured from "contradictory and conflicting" to "compatible." The theory argues that there has been a shift in the discourse on environmental policy and corporate strategy or descriptions of "social and institutional transformation" rather than there being a "physical improvement" of environmental conditions [13]. The focus of policy domain has expanded from preventing environmental pollution to increasing efficiency. It also now includes lifecycle thinking, represented by the concepts of material cycles, lifecycle analysis and industrial ecology.

In other words, SCP 2.0 shows that environmental sustainability can be achieved by more efficient use of materials and energy throughout the product lifecycle and at the value-chain level [29]. SCP 2.0 aims at harmonizing the environment and economy towards sustainability by increasing efficiency throughout the product lifecycle at the product level or facility-unit level. Chemical management, waste management, and recycling can now be seen as a part of product management system from lifecycle perspective.

We can see the concept of SCP 2.0 in Toyota's marketing strategy for its hybrid vehicle, the Prius, released on 10 December 1997, to coincide exactly with the timing of the third Conference of the Parties to the UN Framework Convention on Climate Change (COP3) held in Kyoto, Japan from 1 to 11 December 1997. The Prius was marketed as environmentally friendly, incorporating technological innovation in response to global warming. The main marketing strategy for the Prius was its low environmental impact and high energy-saving potential. The vehicle's internal computer automatically adjusts the driving mechanism to use its electric motor at low speeds, and a combination of the motor and the gasoline engine at normal speed, with electricity stored to the battery. The Prius has low $\mathrm{CO} 2$ emissions and high fuel efficiency throughout its lifecycle. However, critics alleged that, while the Prius might have less environmental impact, production methods are potentially more damaging to the environment than for conventional vehicles. In response to this criticism, Toyota used lifecycle assessment (LCA) to calculate the CO2 emissions over the vehicle's lifecycle and proved that the Prius actually emitted 36\% fewer emissions over its lifecycle (Toyota, Environmental Report 1999, 1999). The launch of the Prius came four years earlier than the Japanese government's introduction of a green tax mechanism for automobiles in 2001.

SCP 2.0 mainstreamed the efficient use of energy and resources throughout the product lifecycle. In the product manufacturing and utilization stage (upstream), SCP 2.0 aimed to improve energy efficiency and product recyclability, as well as to pursue environmentally friendly design and efficient production. After the product is used (downstream), it is more important to focus on waste reduction, reuse, recycling, and environmentally appropriate treatment. The lifecycle of products and materials can be divided into: resource extraction, production/manufacturing, distribution, consumption, recycling, and waste management. Lifecycle thinking for policy intervention usually place policies regulating environmental impacts in each lifecycle stage, or incorporates environmental externalities in each lifecycle stage or in a combination of different lifecycle stages [30,31]. However, a lifecycle-based approach is considered to be part of policy interventions for individual products, services, or material streams such as plastics, home appliances, automobiles, or food. In addition, the role of consumption tends to be downplayed as a driving force for product and service system. Instead, consumption represents one stage of the whole system.

Nevertheless, SCP 2.0 follows the lines of conventional economic development and incremental changes. For example, Steinberger and Krausmann symbolically criticize resource productivity as a well-referred indicator to measure the policy progress of a resource-efficient sustainable economy [32] and argue that this indicator is correlated with GDP as income, so richer countries tend to benefit more from a higher resource productivity indicator [33]. However, there are increasing concerns about the so-called "rebound effects", which can undermine the environmental gains made in resource efficiency. It is widely acknowledged that improvements in unit-level and product-level resource and energy efficiency do not necessarily result in an overall reduction in energy and resource 
consumption [34-37]. In this context, the limitations of efficiency discourse have been gradually recognized.

\subsection{SCP 3.0: Transition and Sufficiency}

We are now observing a significant expansion in the SCP policy domain, comparable to the expansion from SCP 1.0 to SCP 2.0 described by ecological modernization theory. In light of concerns regarding the rebound effect [34-36,38] and the implied limitations of efficiency improvement in products and services, there is growing awareness of the need to create socio-technical systems that enable or constrain behavior and reduce consumption of non-renewable resources/materials [39-42] such as fossil fuels and plastics.

Socio-technical systems require urgent policy intervention to encourage the demand side/civil sector to transition to a sustainable regime, by modifying business models, lifestyles, and infrastructure. The current mainstreamed SCP 2.0 tends to be technically oriented and primarily focuses on the individual product, unit and facility, or on the behavior of individuals $[43,44]$, rather than on societal and technical dynamics beyond a single product system. Indeed, the study on social practices and climate change emphasizes the need for change in terms of the interdependence of social practices on consumption rather than individual behavior [45]. Only by pushing forward with these dynamics can we hope to make the systemic changes to physical and social infrastructures necessary for sustainable business models and lifestyles.

A focus on efficiency has its limitations if we want to control ever-increasing demand and consumption. Trying to find a way to overcome these limitations since the 2000s, the expert community has been examining the principle of sufficiency $[9,14,28,29]$, which has been seen as a new concept for decision-making on sustainability [46]. Huber defines the policy approach on sufficiency as "a strategy of self-limitation of material consumption within the boundaries of low-level production and consumption". In contrast, efficiency is defined as "a strategy to allow further economic growth and ecological adaptation of industrial production by improving the environmental performance, i.e., improving the efficient use of material and energy, thus increasing resource productivity in addition to labour and capital productivity". This definition has been discussed as a main feature of SCP 2.0 in this paper.

In contrast to efficiency, Princen defines sufficiency as a principle which is "a sense of enoughness and too muchness" and "social restraint as the logical analog to ecological constraint" $[47,48]$. Boulanger also makes a contrast between sufficiency strategy and efficiency strategy for sustainable consumption, stating that sufficiency strategy "striv[es] to get the maximum wellbeing from each unit of material service consumed" as well as "minimize[s] the role of material services in the definition and production of wellbeing" [44]. Spengler emphasizes that environmental sustainability based on sufficiency is motivated by the limits of environmental capacity, by the cumulative consequences of modern consumption patterns, and by the promotion of an additional solution besides a "technical fix" [43].

In the second half of the 2010s, sufficiency discourse has been implicitly or explicitly emphasized in international policy processes including climate change and sustainable development, as discussed in the next section. This idea of sufficiency in mainstream policy discussion has emerged in line with need for a transition of lifestyles and infrastructure as summarized in Table 1.

Studies and discussions on SCP [49-54] point out that sustainable consumption patterns as well as social practices including lifestyles cannot be detached from infrastructure setting. For example, studies by Shove on the relationship between social practices and consumption emphasizes that consumption is not a sum of individual behavior but a socio-technical system of daily routines based on various infrastructures controlled by cultural, economic and technological drivers [55]. By using LCA methodology, Tukker et al. identifies provision systems associated with final consumption domains such as housing, mobility, and food as the key drivers of material and energy consumption and production [56]. Similarly, UNEP's "Sustainable Consumption and Production: A Hand- 
book for Policy Makers" [3] clearly articulates the need to make a shift in lifestyle domain and policy focus to food, housing, and transportation. Strategic investment is also required for sustainable infrastructure. Akenji [57], as well as UNEP [3], argues that it is necessary to focus on the shift in infrastructure of energy production and provisions, housing, and the transport system or urban development for more fundamental changes.

Focusing on lifestyle and infrastructure is one way to overcome limitations and increase the efficiency of individual products and their lifecycles. At the same time, there is a growing awareness that environmental education and consumer awareness are not enough to change the behavior of consumers because of the so-called lock-in effect [58]. This means that consumer behavior is determined by infrastructure and selection of products and services. Raising awareness is not enough to change behavior-there also needs to be a change in social design. In another example, Akenji emphasizes that adoption of a sustainable lifestyle is influenced by the design of provision systems and infrastructure which predetermine the level of flexibility, and appropriate infrastructure can enable sustainable lifestyles [57].

By reviewing major SCP-related studies from 2000 to 2010, Cohen et al. points out that policy debate on SCP had expanded to include "the prospects of transitions toward sociotechnical regimes that could enable more sustainable modes of consumption" [59]. Soler et al. argues that material and institutional infrastructures, which are systems providing the operational basis for products and services, enable and support sustainable consumption by making sustainable products and services accessible and convenient while penalizing unsustainable ones [52]. The concept of one planet living by BioRegional is one example of how sustainable lifestyles are conceptualized [60]. By using the headline indicators of ecological footprint and carbon footprint, BioRegional suggests ten principles for one planet living - health and happiness, equity and local economy, culture and community, land use and wildlife, sustainable water, local and sustainable food, sustainable materials, sustainable transport, zero waste, and zero carbon [61]. In a similar way, Spengler [43] positions the sufficiency concept as a central policy concept for emerging areas of SCP such as mobility, housing, appliances, and products, emphasizing that "[s]ufficiency as policy would ... shift the idea from being an individualistic strategy to reduce the environmental impacts of one's personal consumption pattern to the collective level, in search of policy options that support or even require such changes in consumption patterns" [62].

Thus, SCP 3.0 emphasizes the importance of socio-technical system change and innovation, as well as the transition towards sustainability. Policy debate under SCP 3.0 is characterized by ambitious policy goals which require socio-technical transition as well as a roadmap to achieve such goals.

Policy discussions under SCP 3.0 are strongly linked to increasing awareness on planetary boundaries $[63,64]$. The concept of planetary boundaries is also linked to our carbon footprint and ecological footprint. These indicate the indirect environmental impacts of the supply chain and trade [65]. As the rebound effect suggests [34,35,38,66], we must make changes to our socio-technical systems. Otherwise, however much effort we make on an individual/unit-level to limit material needs and unnecessary consumption, we will not be able to control our current levels of ever-increasing consumption and all the associated ecological impacts. A systematic literature review on sustainable transition by Savaget et al. reveals that literature on sustainable transition mainly deals with how to trigger socio-technical system change [67]. Kohler et al. emphasizes that future challenges for sustainability transition research include widening the scope from focusing on single systems such as energy, mobility, water, food and health to also looking at multi-sector transitions. This could be done by reconfiguring existing socio-technical systems as well as triggering deeper changes on the demand side [68]. 
Table 1. Three phases of SCP policy discourse and domain.

\begin{tabular}{|c|c|c|c|}
\hline Approaches & SCP 1.0 & SCP 2.0 & SCP 3.0 \\
\hline Major concepts & $\begin{array}{l}\text { Pollution prevention } \\
\text { Cleaner Production (as an } \\
\text { intermediate between } \\
\text { SCP } 1.0 \text { and } 2.0 \text { ) }\end{array}$ & $\begin{array}{l}\text { Industrial ecology } \\
\text { Resource efficiency } \\
\text { Product lifecycles }\end{array}$ & $\begin{array}{l}\text { One planet living, } \\
\text { Sufficiency, } \\
\text { Decarbonization } \\
\text { Transition }\end{array}$ \\
\hline Key issues & Industrial pollution & $\begin{array}{c}\text { Climate change, waste, } \\
\text { environmental issues } \\
\text { associated with consumption }\end{array}$ & $\begin{array}{c}\text { Well-being, } \\
\text { Life-style } \\
\text { Socio-technical system }\end{array}$ \\
\hline $\begin{array}{l}\text { Environment-economy } \\
\text { relationship }\end{array}$ & $\begin{array}{l}\text { Separate, contradictory, } \\
\text { confrontational }\end{array}$ & $\begin{array}{l}\text { Compatible, industrialization } \\
\text { harmonized with } \\
\text { environmental conservation }\end{array}$ & $\begin{array}{c}\text { Inclusion of social consideration, } \\
\text { Sustainability as a key for next } \\
\text { socio-technical innovation }\end{array}$ \\
\hline Approaches & $\begin{array}{l}\text { Installation of end of pipe } \\
\text { technologies } \\
\text { Technology and management } \\
\text { for cleaner production }\end{array}$ & $\begin{array}{l}\text { Increasing material and } \\
\text { energy efficiency }\end{array}$ & $\begin{array}{l}\text { Consensus building } \\
\text { Changes in infrastructure } \\
\text { Changes in lifestyles } \\
\text { New business models }\end{array}$ \\
\hline $\begin{array}{l}\text { Major actors and } \\
\text { stakeholders }\end{array}$ & Government vs. industry & $\begin{array}{l}\text { Collaboration of government } \\
\text { and market agents }\end{array}$ & $\begin{array}{l}\text { Social entrepreneurship } \\
\text { Multi-stakeholder } \\
\text { Lifestyles of people }\end{array}$ \\
\hline Attitude of policies & React and cure & Anticipate and prevent & $\begin{array}{l}\text { Long-term goal setting, } \\
\text { investment, creating business } \\
\text { environment, creation and } \\
\text { communication }\end{array}$ \\
\hline
\end{tabular}

Source: Authors partly adopting ecological modernization theory $[5,7,27,28]$.

\section{Emergence of SCP 3.0 in the Recent International Policy Discussions}

As discussed in Section 3.3, in the late 2000s, policy discussions on SCP-related domain expanded to include the systematic transition of socio-technical systems, lifestyles, and infrastructure driving consumption and production (SCP 3.0). We will use this section to highlight how recent international policy discussions on sustainability have begun to express policy discourse similar to SCP 3.0. Progress is being made to set very ambitious long-term and middle-term goals requiring sustainable transition of modern socio-technical systems.

Major international agreements since 2015 have often set ambitious mid-term and long-term goals, including goals on decarbonization or transition to a net zero society, goals to eliminate marine plastic discharge, or goals to achieve one planet living. However, to meet these goals, we need to make fundamental changes to our society, in terms of our lifestyles and infrastructure. In the following subsections, we examine the discourse that has taken place in major international policy discussions in the context of SCP 3.0.

\subsection{The Paris Agreement}

The Paris Agreement (PA) was adopted in December 2015 to strengthen global efforts to tackle climate change impacts. It aims to keep "the global temperature rise this century well below 2 degrees Celsius above pre-industrial levels and to pursue efforts to limit the temperature increase even further to 1.5 degrees Celsius." Article 4 of the PA also sets out to "undertake rapid reductions thereafter in accordance with best available science, so as to achieve a balance between anthropogenic emissions by sources and removals by sinks of greenhouse gases in the second half of this century". This is interpreted as net zero emissions of GHGs by the latter half of this century and often labeled as "de-carbonization". Thus, it is argued that the long-term goal of the PA implies the necessity of de-carbonization and de facto zero emissions of GHGs towards the second half of the 21st century [69].

Although one of the limitations of the PA is the non-compulsory nature of its main approach to achieving NDCs (Nationally Determined Contributions), many countries are now setting ambitious mid-term and long-term goals at the national level. 
Several European countries including the UK and France have included net zero emission goals in national legislation. The European Union, Canada, Republic of Korea, Spain and Chile put net zero emission goals in their proposed legislation. Major countries including the US, Japan, South Africa, Germany, and China included net zero emission goals by 2050 or 2060 in their official policy documents [70].

Although the scope is limited to carbon emissions, the implementation of the PA can be understood as operationalizing the shift in policy discourse to SCP 3.0 [71,72]. Indeed, Rockstrom et al. argues that the decarbonization target of the PA necessitates a rapid transition including changes in innovation, institutions, infrastructures, and investment [73]. Moreover, the 1.5-degree target requires a significant change in consumption and production patterns including the transition of lifestyles and provision systems [71,74]. The implication of such goal setting is a massive decarbonization of consumption and production systems towards a net zero carbon emission society. Even with extensive application of carbon sequestration technologies, there is no way to avoid making major transitions in energy demand and lifestyles [71,75].

\subsection{G7 Toyama Framework on Material Cycles in 2016}

In 2016, the G7 Environmental Ministers' Meeting in Toyama adopted the G7 Toyama Framework on Material Cycles [76]. This has one vision, three goals, and eight actions. The three goals are (1) Leading domestic policies for resource efficiency and the 3Rs, (2) Promotion of global resource efficiency and the 3Rs, and (3) Steady and transparent followup process. Specific actions in the framework include (1-1) Integration of policies and policy mix, (1-2) Efficient and maximized use of resources, (1-3) Initiatives in cooperation with diverse local actors (industrial and community symbiosis), (1-4) Actions to final demands/consumers, (2-1) Cooperation with other countries, (2-2) Cooperation across the global supply chain, (3-1) G7's domestic efforts, and (3-2) Global efforts. Eight years ago in 2008, G8 adopted the G8 Kobe 3R Action Plan which focuses on 3R policy promotion and environmentally sound waste management in the context of developing countries. Conceptually, 2008 Action Plan embodied SCP 2.0 by emphasizing resource productivity, efficient use of resources, environmentally sound waste management, decoupling between economic development and environmental impacts associated with material uses and waste generation. On the other hand, the 2016 Framework emphasized a more holistic policy approach for sustainable resource management, decentralized actions, attention to consumers, global value chains, and harmonized actions among the G7 member states.

The 2016 Framework emphasizes that the "common goal is to realize a society which uses resources including stock resources efficiently and sustainably across the whole lifecycle, by reducing the consumption of natural resources and promoting recycled materials and renewable resources so as to remain within the boundaries of the planet, respecting relevant concepts and approaches." The framework clearly mentions "reduction of the consumption of natural resources" to "remain within the boundaries of the planet". At the same time, in action 1-4 on actions to final demands, the framework clearly stated that G7 will "promote increased consumer awareness of the environmental and economic advantages of sustainable consumption; "awareness of sufficiency" — an idea that we should not be greedy, but be satisfied with appropriate amounts; smart purchasing; green public procurement; new services involving reuse, repair, and sharing; and eco-labeling." Although it is stated in the context of sufficiency at behavioral level, this is one case where SCP 3.0 is highlighted in high-level political documents on sustainability.

This expansion from SCP 2.0 to a more integrated approach including the concept of SCP 3.0 in the document on resource efficiency for the G8/G7 is a good indication of how SCP 3.0 is being further mainstreamed at the discursive level in major international policy processes. 


\subsection{Marine Plastic Issues: Ocean Plastic Charter and G20 Osaka Blue Ocean Vision}

One of the most widely discussed agendas in relation to SCP is plastic pollution and marine plastic litter including those related to micro- and nano-plastics. Second only to climate change, it has been a focal issue for discourse in policy circles since the late 2000s International policy attention on marine plastics is not limited to mere pollution prevention. Plastic as a material is deeply integral to every aspect of the current global economy of production and consumption from food and beverage packaging, logistics, textiles, cosmetics, mobility (tires), and construction materials [77]. The New Plastic Economy report by the Ellen Macarthur Foundation describes the symbolic characteristic of plastics in the modern economy as follows: "Plastics have become the ubiquitous workhorse material of the modern economy-combining unrivalled functional properties with low cost" [78], and also emphasizes that "[p]lastic packaging is an iconic linear application with USD 80-120 billion annual material value loss". Thus, it is an issue deeply embedded in our daily lifestyles and in the social infrastructure of our throw-away culture. At the same time, compared to GHGs, plastic pollution is widely more visible both in terms of sources as well as ecological consequences.

Since 2015, the G7 has taken up this issue on its sustainability agenda. In 2015, the G7 Elmau Summit adopted the G7 Action Plan to Combat Marine Litter. The plan mentions the prevention of plastics entering the marine environment as a priority action but did not set any numerical targets. Again in 2016 and 2017, the G7 Ise-Shima Summit and the G7 Bologna Environmental Ministers' Meeting confirmed the importance of priority actions set in the 2015 Action Plan. Then, in June 2018, at the Charlevoix Summit held in Canada, the Ocean Plastics Charter was proposed and adopted by all G7 members, apart from Japan and the US. The preface to the charter stated that "the current approach to producing, using, managing and disposing of plastics poses a significant threat to the environment, to livelihoods and potentially to human health. It also represents a significant loss of value, resources and energy". Interestingly, despite an emphasis on working with industry, the Charter sets several numerical targets such as " $100 \%$ reusable, recyclable, or, where viable alternatives do not exist, recoverable, plastics by 2030", "increasing recycled content by at least $50 \%$ in plastic products where applicable by 2030 ", or "recycle and reuse at least $55 \%$ of plastic packaging by 2030 and recover $100 \%$ of all plastics by 2040 ". However, there is not much reference to a reduction in plastic consumption. Having failed to sign the Ocean Plastics Charter, Japan took urgent action to develop a resource circulation strategy for plastics by the time of its G20 Presidency in 2019, including several numerical targets-total $25 \%$ reduction of generation of single use plastics by $2030,60 \%$ of packaging and containers to be reused and recycled by 2030, among others. This national strategy placed reduction in the use of single-use plastics as one of the main objectives.

In June 2019, G20 leaders adopted the G20 Osaka Blue Ocean Vision. This Vision aims "to reduce additional pollution by marine plastic litter to zero by 2050". If G20 leaders are serious about this vision/goal, they need to make a fundamental socio-technical system change in their societies and economies, which are currently dependent on plastic use and consumption.

\subsection{COVID-19 and Green Recovery}

In this section, we argue that policy discussion on green recovery from the COVID-19 pandemic provides an unprecedented opportunity to make the transition to sustainability [79], at least at the discursive level. For example, the OECD presents green recovery from the pandemic as the greatest opportunity for "building back better" including "alignment with long-term emission reduction goals, factoring in resilience to climate impacts, slowing biodiversity loss and increasing circularity of supply chains" [80]. OECD's policy recommendations include: (1) "screening all elements of stimulus packages for their longer terms implications" for net-zero GHG emissions, strengthening climate resilience, reduction in biodiversity loss, innovation based on behavioral change, and improvement in circularity, (2) "building pipelines of "shovel-ready" sustainable infrastructure projects", 
and (3) maintaining and increasing ambition of long-term environmental objectives. There has also been more policy research emphasizing the importance of a green recovery plan in line with long-term climate goals [81-83]. We have seen unprecedented changes in lifestyles, business models and infrastructure during this COVID-19 pandemic, and a green recovery from this global crisis would encourage further experimental socio-technical system changes along with other long-term sustainability goals [84].

\subsection{Conceptual Change in International Policy}

These examples of recent major international agreements and policy discussions on sustainability show that there have been ambitious goals set on absolute reduction. These goals have been for primary material and energy consumption, or for the associated environmental impacts requiring fundamental socio-technical system change. This ambitious goal-setting based on planetary boundaries echoes the sufficiency concept, but also requires a radical shift in our socio-technical system (transition). Indeed, as Tukker et al. rightly predicted in 2008, we can see that "a rough agreement on goals exists, but where change is radical, or means are uncertain .... planning [is] difficult" [85]. Thus, policy design should contribute to foster "visioning, experimentation, and support [85]" for a sustainable transition.

\section{Discussion: Emerging Challenges and Opportunities for Policy Design for SCP 3.0}

Policy domain and policy design interact with each other. For example, the goals and objectives of SCP policy design under SCP 1.0 aimed at preventing environmental pollution by introducing end-of-pipe technologies, as well as altering production processes by integrating externalities. SCP 1.0 was about how to harmonize separate, contradictory, and confrontational relationships between the environment and the economy, as highlighted in the concept of CP. For SCP 2.0, sustainability challenges were widened from direct environmental pollution to include more indirect issues such as climate change and waste which were driven by globalized consumption and production. Different policy instruments have been used at different stages of product lifecycle, services and materials. Efficiency was promoted, making the environment and economy more compatible. Under SCP 3.0, the objectives and goals of SCP policy design expanded beyond environmental policy and strategy to include socio-technical system design. This was necessary to maintain the well-being of society as a whole, encouraging a transition to a sustainable lifestyle through consensus on changes for infrastructure and business. In this final section, we argue that expansion and mainstreaming of the SCP policy domain from SCP 2.0 to SCP 3.0 creates challenges and opportunities for effective policy design, with reference to the arguments in the articles in this special issue.

Firstly, although many recent international agreements and related national action plans on sustainability have set very ambitious long-term and mid-term goals, it is not clear what society will look like after it has achieved those goals-we do not know what kind of industry, infrastructure, business models and lifestyles there will be and how they will operate. Therefore, the first priority for policy design is to envision concrete images of a society that has successfully met its mid-term and long-term goals. We can use a scenario-based approach to trace pathways to the future. Börjeson et al. [86] points out that there are three scenarios: predictive, exploratory, and normative. These correspond to questions about the future: "What will happen?", "What can happen?" and "How can a specific target be reached?". A backcasting approach is typical for a normative analysis and is defined as "generating a desirable future, and then looking backwards from that future to the present in order to strategize and to plan how it could be achieved" [87]. Exploratory analysis refers to what can happen. Policy design for SCP 3.0 requires both perspectives. We must ask what can happen to a society once it has achieved specific targets, and attempt to create a vision of such a society. One of the most famous attempts is the shared socioeconomic pathways (SSPS). This scenario was the successor of SRES that was used for the IPCC 4th assessment report [88]. SSPS will be applied for socio-economic 
scenario development in the IPCC 6th assessment report [89-91]. The Paris Agreement prompted global discussions on how to achieve net zero carbon emissions and how to change socio-technical systems, including discussions by IEA [92] and UK Climate Change Committee [93]. For example, Kawakami et al. analyzes what a decarbonized society would look like in Japan, under a conventional incremental reform scenario and under a more decentralized transition scenario [94]. In terms of a vision for policy design, Mont et al. developed different extreme scenarios for sustainable lifestyles in 2050 [95]. To facilitate policy dialogue and design, Kishita et al. attempts to combine a backcasting approach with a workshop-style dialogue to create a vision on SCP for developing Asia in 2050 [96]. In this special issue, Mao et al. apply a foresight study approach when designing policy for a long-term transition to a sustainable lifestyle [97]. However, it is still not clear how effective this type of envisioning or scenario approach really is, and more insights are needed. In the era of SCP 3.0, envisioning a future society and lifestyle will be a crucial part of policy design.

Secondly, it is not yet clear how we can turn these visions into reality and how policy can support, promote, and guide us in that endeavor. What is clear is that policymakers need to mobilize investment, they need to create enabling conditions by making changes to regulations and incentive structure, as well as awarding and informing best practices. There also needs to be policy support for learning from model cases, projects, and businesses to achieve a long-term and mid-term vision. In this special issue, Watabe and Gilby attempt to show how local stakeholders can continue to work on model projects through capacity development and learning processes [98]. By examining local context for implementing SDGs, Liu and Nguyen attempted to provide policy recommendation to reduce food waste along the entire supply chain and promote sufficiency strategies for saving food, reducing food waste, and maintaining health and well-being towards SDGs Target 12.3, based on Hanoi's case study [99]. Additionally, for policy-driven sustainability transition, Kohdke et al. emphasizes importance of accounting for the dynamic positioning of stakeholder involved in collaborative efforts for transition [100]. Better understanding of dynamism among stakeholders can deepen the understanding of the challenges of implementation, particularly adaption of timelines for implementation based on changing capacity and needs of stakeholders. More studies should be done to design policy that can turn a vision into reality.

Thirdly, it is important to evaluate whether a realized vision is truly beneficial for the environment and for sustainability. This requires both policy to collect evidence for realizing a vision and then evidence-based policy making (EBPM). EBPM often refers to decision-making on policy that takes account of "multiple sources of information, including statistics, data and the best available research evidence and evaluations" [101]. Experts and stakeholders can inform decision-making by carefully analyzing and demonstrating what the actual impacts would be for a variety of options for a future vision. There is one major criticism of EBPM and that is its over-reliance on rationality [102]. Kano and Hayashi [103] present a wider understanding of EBPM with five perspectives: (1) methodological rigorousness, (2) consistency, (3) proximity, (4) social appropriateness, and (5) legitimacy. However, future-oriented policymaking in the era of SCP 3.0 is a creative process rather than an evaluation of different policy options. Thus, we need to discuss whether or not EBPM in combination with creating and sharing a vision based on these mid- to long-term goals is different from standard EBPM.

Fourthly, when we look to implement and monitor actions to achieve mid-to-long term goals such as decarbonization, a plastic-free society, green recovery from COVID 19, and the SDGs, we must take care not to evaluate sustainability just from economic and environmental points of view. For example, the combined crises of the COVID-19 pandemic and the Paris Agreement can be used to drive policy interests and expectations further on prospects and innovation towards decarbonization, digitalization, and transition to sustainable lifestyles and infrastructure. Additionally, these two combined crises prompted us to reemphasize that equity, safety, welfare, health and education as well as associated 
public services are fundamental issues for social sustainability. Education has been reconfirmed as being key for social integrity and individual well-being, with consumption to enrich social capital also being important. In this respect, Tsurumi et al. [104] attempts a detailed analysis on the relationship between attitude, consumption behavior, social capital and subjective well-being of people through a case study of rural habitats in Viet Nam. In addition, a study by Piao et al. examines the relationship between a sustainable lifestyle and the essential needs of citizens such as education and health [105]. There are likely to be widespread and fundamental social impacts from a sustainable transition, and policy research on SCP needs to examine the various ways that sustainable lifestyles and associated infrastructure would function.

We tentatively coin the policy design approach responding to the above four challenges of SCP 3.0 as "Envisioning-based Policy Making (EnBPM)" by incorporating the importance of envisioning approach related to SCP 3.0 beyond EBPM as discussed above. Figure 1 illustrates our idea of EnBPM in contrast to EBPM. The coverage of EBPM tends to focus more on direct policy targets, policy implementation and its effectiveness so as to provide a strong evidence with attention to rigorousness and consistency [103]. EnBPM covers wider policy concerns such as future visions of sustainable society, social experimentation of such societal visions before full policy implementation based on long-term goals as well as social sustainability. EnBPM would require a more decentralized and collaborative approach for policy design based on working together to envision and realize future directions of the society among stakeholders because it puts importance on social appropriateness about sustainability rather than EBPM. A vision is created based on prototypes (community and business models) with decentralized coordination among various initiatives. Communication tools and decision support tools that can share the direction of transition would be important as a catalyst for self-sustained, decentralized efforts in various sectors. Again, we observed the importance of framing, interpretation, and generating storylines not only to provide narratives for the past experiences but also to provide future-oriented storylines with research-based evidence.

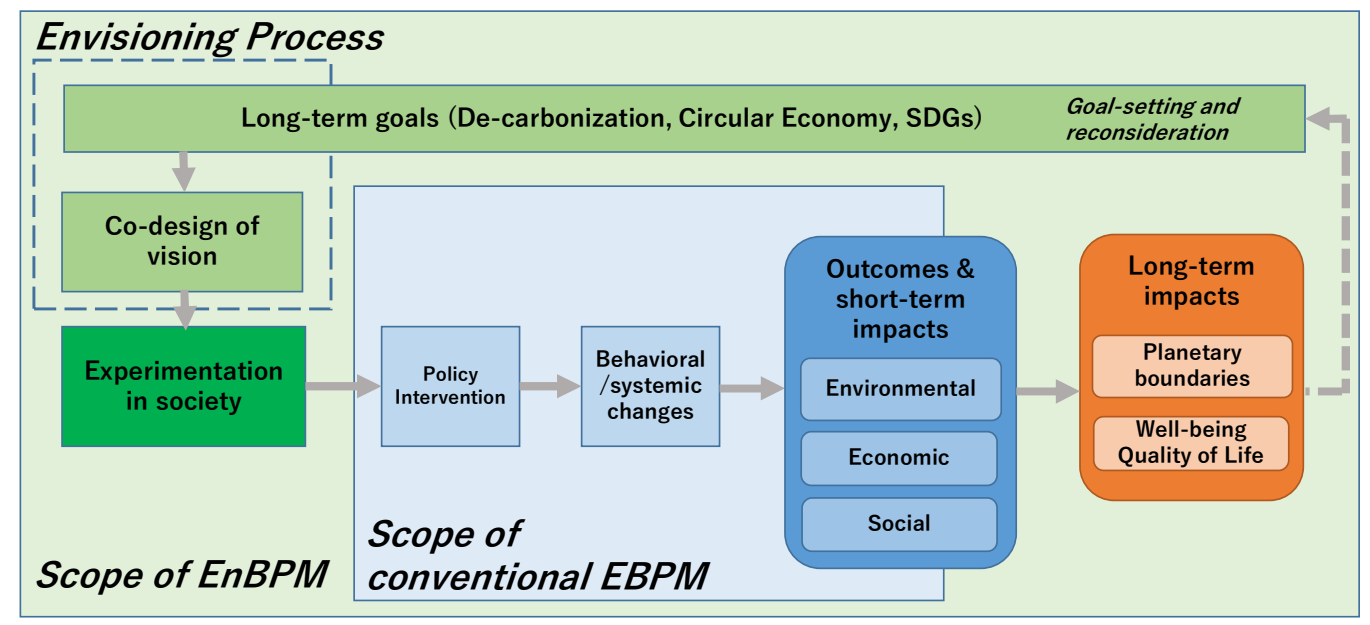

Phase of policy process $\bigcirc$ Policy consequences and evaluation results

Figure 1. EBPM and EnBPM towards sustainability. Source: Modified and developed from Figure 1 of [106] by authors.

\section{Conclusions}

This paper argued that policy discussion on SCP is a major expression of the sustainability agenda, and that this discourse has expanded from pollution prevention (SCP 1.0) to lifecycles (SCP 2.0), then to transition (SCP 3.0). For policy discussions on sustainability, it is very important to better understand how SCP is discussed in the different contexts of SCP 1.0, SCP 2.0 and SCP 3.0. Each country and communitytable has different policy priorities [106], and consequently, discussions tend to focus on one of the three SCP 
phases-SCP1.0, 2.0 and 3.0- or as a combination of these three versions. We could in fact have a hybrid concept, whereby three different but related contexts of environmental policy development endeavor to achieve SCP in a phased manner from SCP 1.0 to SCP 3.0. This could be especially pertinent for emerging economies.

One of the major features of recent international policy agreements is that they have set ambitious long and mid-term goals based on the concept of planetary boundaries. This resulted in an expansion of policy domain from environmental sustainability to socio-technical systems change (SCP 3.0). These changes in emphasis in policy goals and approaches also resulted in the need for a fresh approach for SCP policy design.

The challenge facing SCP policy design in this context is the development of model cases, and a social image or vision. Emerging opportunities and challenges for policy design for SCP 3.0 include: (1) envisioning concrete images of a society that has successfully met its mid-term and long-term goals, (2) policy support for learning from model cases, experimental projects, and new businesses to achieve a long-term and mid-term vision, (3) facilitating creative process among stakeholders, and (4) examination of social implications of innovation towards decarbonization, digitalization, and transition to sustainable lifestyles and infrastructure. To deepen the debate on SCP policies required in the future, it is necessary to change our way of thinking on environmental policies. As a policy design approach in response to these challenges and opportunities, the paper proposed the concept of Envisioning-based Policy Making (EnBPM). In the era of SCP 3.0, policy design and scientific research on SCP can provide rich opportunities and challenges to bring together creative visions, future scenarios, social experimentation, stakeholder engagement, urban and spatial planning, new indicator development, lifestyles and social sustainability, and new business model development. Conventional regulations and economic tools must work to introduce a new approach and innovation into lifestyles and infrastructure [107]. We need to develop a social business model and promote public and private investment to facilitate model cases which can enhance storylines for sustainable transition. We must come up with new business or social model development and social designs within planetary boundaries, and incorporate them into the central agenda of SCP policy. Communication and decision-support tools will also play an important role to promote stakeholder collaboration and dialogue. In that sense, there are rapidly emerging opportunities for collaboration between policy design and scientific research on SCP for envisioning and developing model cases which can generate compelling storylines for SCP 3.0.

Author Contributions: Formal analysis, Investigation, Supervision, Writing—original draft, Y.H.; Conceptualization, Y.H., T.T., and R.K.; Writing — review \& editing, T.T. and R.K. All authors have read and agreed to the published version of the manuscript.

Funding: This paper was developed based on the research funded by the Environment Research and Technology Development Fund (S-16-3: JPMEERF16S11630, S-16-2: JPMEERF16S11620) of the Environmental Restoration and Conservation Agency, Japan.

Acknowledgments: The authors would like to express their appreciation to Emma Fushimi of IGES for her careful editing and proof reading of the entire manuscript as well as to Chen Liu of IGES for her review and insightful comments to improve the earlier draft.

Conflicts of Interest: The authors declare no conflict of interest.

\section{References}

1. Conca, K. Consumption and Environment in a Global Economy. Glob Environ. Polit. 2001, 1, 53-71. [CrossRef]

2. United Nations. Agenda 21: The United Nations Programme of Action from Rio. In Proceedings of the United Nations Conference on Environment \& Development, Rio de Janeiro, Brazil, 3-14 June 1992.

3. United Nations Environment Programme (UNEP). Sustainable Consumption and Production: A Handbook for Policy Makers; Global Edition; United Nations Environment Programme: Nairobi, Kenya, 2015.

4. Fairhead, J.; Leach, M. Science, Society and Power: Environmental Knowledge and Policy in West Africa and the Caribbean; Cambridge University Press: Cambridge, UK, 2003. 
5. Hajer, M.A. The Politics of Environmental Discourse; Oxford University Press: Oxford, UK, 1997; Available online: http://www. oxfordscholarship.com/oso/public/content/politicalscience/019829333X/toc.html (accessed on 25 March 2021).

6. Litfin, K. Ozone Discourse: Science and Politics in Global Environmental Cooperation; Basic Books: New York, NY, USA, 1994.

7. Dryzek, J. The Politics of the Earth: Environmental Discourses; Oxford University Press: Oxford, UK, 1997.

8. Hawkins, A. Contested Ground: International Environmentalism and Global Climate Change. In State of Social Power in Global Environmental Politics; Lipschutz, R.D., Conca, K., Eds.; Columbia University Press: New York, NY, USA, 1993.

9. Lipshcutz, R.D.; Conca, K. The State and Social Power in Global Environmental Politics; Columbia University Press: New York, NY, USA, 1993.

10. Ganz, M. Leading Change-Leadership, Organization and Social Movements. In Handbook of Leadership, Theory and Practice, an HBS Centennial Colloquim on Advancing Leadership; Harvard Business Press: Boston, MA, USA, 2010.

11. Jänicke, M.; Weidner, H. Successful Environmental Policy-A Critical Evaluation of 24 Cases; Sigma: Berlin, Germany, 1995.

12. Jänicke, M.; Mönch, H.; Binder, M. Structural Change and Environmental Policy. In The Emergence of Ecological Modernisation; Routledge: London, UK, 2000; p. 133. Available online: https://www.taylorfrancis.com/chapters/structural-changeenvironmental-policy-martin-jänicke-harald-mönch-manfred-binder/e/10.4324/9781315812540-6 (accessed on 25 March 2021).

13. Mol, A.P.J.; Sonnenfeld, D.A. Ecological Modernisation Around the World: Perspectives and Critical Debates; Frank Cass: Portland, OR, USA; Routledge: London, UK, 2000.

14. Mitsuhashi, T. Kankyo Keizai Nyumon (Introduction to Environmental Economics); Nikkei: Tokyo, Japan, 1999.

15. Nakanishi, J. Mizu no Kankyo Senryaku (Global Water Strategy); Iwanami: Tokyo, Japan, 1994.

16. United Nations Environment Programme (UNEP). Understanding Resource Efficient and Cleaner Production. Available online: http:/ / www.unep.fr/scp/cp/understanding/ (accessed on 5 March 2021).

17. United Nations Environment Programme (UNEP). Government Strategies and Policies for Cleaner Production. Available online: https:/ / wedocs.unep.org/handle/20.500.11822/29358 (accessed on 5 March 2021).

18. United Nations Environment Programme (UNEP). Promoting Cleaner Production Investments in Developing Countries. Available online: https: / / www.unep.org/resources/report/dtie-activities-and-performance (accessed on 5 March 2021).

19. United Nations Industrial Development Organization (UNIDO). Manual on the Development of Cleaner Production PoliciesApproaches and Instruments. Available online: https://www.unido.org/sites/default/files/2007-11/9750_0256406e_0.pdf (accessed on 5 March 2021).

20. United Nations Environment Programme. Global Outlook on SCP Policies; United Nations Environment Programme: Nairobi, Kenya, 2011.

21. Vanham, D.; Leip, A.; Galli, A.; Kastner, T.; Bruckner, M.; Uwizeye, A. Environmental footprint family to address local to planetary sustainability and deliver on the SDGs. Sci. Total Environ. 2019, 693, 133642. [CrossRef] [PubMed]

22. Wiedmann, T.; Lenzen, M. Environmental and Social Footprints of International Trade. 2018. Available online: https://www. nature.com/articles/s41561-018-0113-9 (accessed on 1 April 2021).

23. Rudolph, A.; Figge, L. Determinants of Ecological Footprints: What is the role of globalization? Ecol Indic. 2017, 81, 348-361. [CrossRef]

24. Christoff, P. Ecological modernisation, ecological modernities. Env Polit. 1996, 5, 476-500. [CrossRef]

25. Huber, J. Towards industrial ecology: Sustainable development as a concept of ecological modernization. J. Environ. Policy Plan. 2000, 2, 269-285. [CrossRef]

26. Mol, A.P.J. Ecological modernisation and institutional reflexivity: Environmental reform in the late modern age. Environ. Polit. 1996, 5, 302. [CrossRef]

27. Weale, A. The New Politics of Pollution; Manchester University Press: Manchester, UK, 1992.

28. Jänicke, M.; Weidner, H. Successful Environmental Policy: An Introduction in Successful Environmental Policy; Edition Sigma: Berlin, Germany, 1995.

29. Von Weizsacker, E.; Lovins, A.B.; Lovins, L.H. Factor Four: Doubling Wealth-Halving Resource Use; Earthscan: London, UK, 1997.

30. Bengtsson, M.; Hotta, Y.; Hayashi, S.; Akenji, L. Policy Tools for Sustainable Materials Management: Applications in Asia; Institute for Global Environmental Strategies: Kanagawa, Japan, 2010; pp. 1-37.

31. Aoki-Suzuki, C. Examining Future Implementation of Waste Prevention and Resource Reduction Policies in Asia and the Pacifi c-Referring Practices in European Countries, Hayama, Japan. Available online: https://www.iges.or.jp/jp/pub/examiningfuture-implementation-prevention-and/en (accessed on 25 March 2021).

32. Government of Japan. Basic Act for Establishing a Sound Material Cycle Society; Government of Japan: Tokyo, Japan, 2000.

33. Steinberger, J.K.; Krausmann, F. Material and Energy Productivity. Environ Sci Technol. 2011, 45, 1169-1176. [CrossRef]

34. Hertwich, E.G. Consumption and the rebound effect: An industrial ecology perspective. J. Ind. Ecol. 2005, 9, 85. [CrossRef]

35. Maxwell, D.; Owen, P.; McAndrew, L.; Muehmel, K.; Neubauer, A. Addressing the Rebound Effect, a Report for the European Commission DG Environment. Available online: http:/ / ec.europa.eu/environment/archives/eussd/pdf/rebound_effect_report. pdf (accessed on 25 March 2021).

36. Polimeni, J.M.; Mayumi, K.; Giampietro MAlcott, B. The Myth of Resource Efficiency: The Jevons Paradox; Earthscan: London, UK, 2008.

37. Schettkat, R. Analyzing Revound Effects. Wuppertal Papaers. Available online: https://epub.wupperinst.org/frontdoor/index/ index/docId/3202 (accessed on 25 March 2021). 
38. Herring, H.; Sorrell, S. Energy Efficiency and Sustainable Consumption: The Rebound Effect; Palgrave Macmillan: Basingstoke, UK, 2009.

39. Akenji, L.; Bengtsson, M.; Bleischwitz, R.; Tukker, A.; Schandl, H. Ossified materialism: Introduction to the special volume on absolute reductions in materials throughput and emissions. J. Clean Prod. 2016, 132, 1-12. [CrossRef]

40. Lettenmeier, M.; Liedtke, C.; Rohn, H. Eight Tons of Material Footprint-Suggestion for a Resource Cap for Household Consumption in Finland. Resources 2014, 3, 488-515. [CrossRef]

41. Bringezu, S. Possible target corridor for sustainable use of global material resources. Resources 2015, 4, 25-54. [CrossRef]

42. Kalmykova, Y.; Rosado, L.; Patrício, J. Resource consumption drivers and pathways to reduction: Economy, policy and lifestyle impact on material flows at the national and urban scale. J. Clean. Prod. 2016, 132, 70-80. [CrossRef]

43. Spengler, L. Sufficiency as Policy. In Sufficiency as Policy-Necessity, Possibilities and Limitations; Nomos Verlagsgesellschaft: Baden-Baden, Germany, 2018.

44. Boulanger, P.M. Three strategies for sustainable consumption. Sapiens 2010, 3. Available online: http://journals.openedition.org/ sapiens/1022 (accessed on 1 April 2021).

45. Shove, E.; Spurling, N. Sustainable Practices: Social Theory and Climate Change, 1st ed.; Routledge: London, UK, 2013.

46. Lamberton, G. Sustainable sufficiency-An internally consistent version of sustainability. Sustain. Dev. 2005, 13, 53-68. [CrossRef]

47. Princen, T. Principles for Sustainability: From Cooperation and Efficiency to Sufficiency. Glob. Environ. Polit. 2003, 3, 33-50. [CrossRef]

48. Princen, T. The Logic of Sufficiency; The MIT Press: Cambridge, MA, USA, 2005.

49. Geels, F.W.; McMeekin, A.; Mylan, J.; Southerton, D. A critical appraisal of Sustainable Consumption and Production research: The reformist, revolutionary and reconfiguration positions. Glob. Environ. Chang. 2015, 34, 1-12. [CrossRef]

50. Dong, L.; Wang, Y.; Scipioni, A.; Park, H.S.; Ren, J. Recent progress on innovative urban infrastructures system towards sustainable resource management. Resour. Conserv. Recycl. 2018, 128, 355-359. [CrossRef]

51. Spaargaren, G.; Oosterveer, P. Citizen-consumers as agents of change in globalizing modernity: The case of sustainable consumption. Sustainability 2010, 2, 1887-1908. [CrossRef]

52. Solér, C.; Koroschetz, B.; Salminen, E. An infrastructural perspective on sustainable consumption-Activating and obligating sustainable consumption through infrastructures. J. Clean. Prod. 2020, 243, 118601. [CrossRef]

53. Kennedy, E.H.; Cohen, M.J.; Krogman, N.T. Social Practice Theories and Research on Sustainable Consumption. In Putting Sustainability into Practice; Kennedy, E.H., Choen, M.J., Krogman, N.T., Eds.; Edward Elger: Cheltenham, UK, 2015.

54. Shove, E.; Walker, G. Governing transitions in the sustainability of everyday life. Res. Policy 2010, 39, 471-476. [CrossRef]

55. Shove, E. Comfort, Cleanliness and Convenience: The Social Organization of Normality; Berg Publishers: Oxford, UK, 2003.

56. Tukker, A.; Jansen, B. Environmental Impact of Products. J. Ind. Ecol. 2006, 10, 159-182. [CrossRef]

57. Akenji, L. Consumer scapegoatism and limits to green consumerism. J. Clean. Prod. 2014, 63, 13-23. [CrossRef]

58. Sanne, C. Willing consumers-Or locked-in? Policies for a sustainable consumption. Ecol. Econ. 2002, 42, 273-287. [CrossRef]

59. Cohen, M.J.; Brown, H.S.; Vergragt, P.J. Individual consumption and systemic societal transformation: Introduction to the special issue. Sustain. Sci. Pract. Policy 2010, 6, 6-12. [CrossRef]

60. Francis, A.; Wheeler, J. BioRegional and World Wide Fund for Nature: One Planet Living; World Wildlife Fund (WWF): Gland, Switzerland, 2004.

61. Bioregional. Implementing One Planet Living: A manual. Available online: https://www.oneplanetnetwork.org/sites/default/ files/implementing_one_planet_living_a_manual.pdf (accessed on 25 March 2021).

62. Spengler, L. Two types of 'enough': Sufficiency as minimum and maximum. Environ. Polit. 2016. [CrossRef]

63. Steffen, W.; Richardson, K.; Rockstrom, J.; Cornell, S.E.; Fetzer, I.; Bennett, E.M. Planetary boundaries: Guiding human development on a changing planet. Science 2015, 347, 1259855. [CrossRef]

64. Raworth, K. Doughnut Economics: Seven Ways to Think Like a 21st-Century Economist; Random House: New York, NY, USA, 2017.

65. O'Neill, D.W.; Fanning, A.L.; Lamb, W.F.; Steinberger, J.K. A good life for all within planetary boundaries. Nat. Sustain. 2018, 1, 88-95. [CrossRef]

66. Sorrell, S.; Dimitropoulos, J. The rebound effect: Microeconomic definitions, limitations and extensions. Ecol. Econ. 2008, 65, 636-649. [CrossRef]

67. Savaget, P.; Geissdoerfer, M.; Kharrazi, A.; Evans, S. The theoretical foundations of sociotechnical systems change for sustainability: A systematic literature review. J. Clean. Prod. 2019, 206, 878-892. [CrossRef]

68. Köhler, J.; Geels, F.W.; Kern, F.; Markard, J.; Onsongo, E.; Wieczorek, A. An agenda for sustainability transitions research: State of the art and future directions. Env. Innov. Soc. Transit. 2019, 31, 1-32. [CrossRef]

69. United Nations. Framework Convention on Climate Change-Paris Agreement. In Proceedings of the 21st Conference of the Parties, Paris, France, 30 November-11 December 2015; p. 3.

70. Energy \& Climate Intelligence Unit. Net Zero Emissions Race. 2020. Available online: https://eciu.net/netzerotracker (accessed on 25 March 2021).

71. Institute for Global Enrvironmental Strategies; Aalto University; D-mat Ltd. 1.5-Degree Lifestyles: Targets and Options for Reducing Lifestyle Carbon Footprints; Technical Report; Institute for Global Environmental Strategies: Hayama, Japan, 2019; Available online: https:/ / www.aalto.fi/sites/g/files/flghsv161/files/2019-02/15_degree_lifestyles_mainreport.pdf (accessed on 25 March 2021). 
72. Akenji, L.; Chen, H. A Framework for Shaping Sustainable Lifestyles Determinants and Strategies-II Acknowledgements. Available online: https:/ / www.iges.or.jp/jp/pub/framework-shaping-sustainable-lifestyles/en (accessed on 25 March 2021).

73. Rockström, J.; Gaffney, O.; Rogelj, J.; Meinshausen, M.; Nakicenovic, N.; Schellnhuber, H.J. A roadmap for rapid decarbonization. Science 2017, 355, 1269-1271. [CrossRef]

74. Koide, R.; Lettenmeier, M.; Kojima, S.; Toivio, V.; Amellina, A.; Akenji, L. Carbon footprints and consumer lifestyles: An analysis of lifestyle factors and gap analysis by consumer segment in Japan. Sustainability 2019, 11, 5983. [CrossRef]

75. Paul, D. SDG 12 Review at HLPF Calls for Circular Economies, Sustainable Lifestyles. 2018. Available online: http:/ / sdg.iisd. org/news/sdg-12-review-at-hlpf-calls-for-circular-economies-sustainable-lifestyles/ (accessed on 25 March 2021).

76. Ministry of the Environment Government of Japan. Communique—G7 Toyama Environment Ministers' Meeting. Ministry of the Environment Government of Japan, 2016. Available online: https://www.env.go.jp/earth/g7toyama_emm/english/_img/ meeting_overview /Communique_en.pdf (accessed on 25 March 2021).

77. United Nations Environment Programme (UNEP); Technical University of Denmark (DTU). Mapping of Global Plastics Value Chain and Plastics Losses to the Environment (with a Particular Focus on Marine Environment); Technical University of Denmark (DTU): Copenhagen, Denmark, 2018; pp. 1-99.

78. Ellen MacArthur Foundation. The New Plastics Economy: Rethinking the Future of Plastics. 2016. Available online: https: //www.ellenmacarthurfoundation.org/publications/the-new-plastics-economy-rethinking-the-future-of-plastics (accessed on 25 March 2021).

79. Cohen, M.J. Does the COVID-19 outbreak mark the onset of a sustainable consumption transition? Sustain. Sci. Pract. Policy 2020, 16, 1-3. [CrossRef]

80. Organisation for Economic Co-operation and Development (OECD). Building Back Better: A Sustainable, Resilient Recovery after COVID. 2020. Available online: https:/ / www.oecd.org/coronavirus/policy-responses/building-back-better-a-sustainableresilient-recovery-after-covid-19-52b869f5/ (accessed on 25 March 2021).

81. Stigl, S. Opportunities of Post COVID-19 European Recovery Funds In Transitioning Towards a Circular and Climate Neutral Economy; European Parliament: Brussels, Belgium, 2020.

82. University of Cambridge Institute for Sustainability Leadership (CISL). Maximising the Benefits: Economic, Employment and Emissions Impacts of a Green Recovery Plan in Europe; Technical Report; CISL: Cambridge, UK, 2020.

83. C40 Knowledge Community. Technical Report: The Case for a Green and Just Recovery. Available online: https://www.c4 0knowledgehub.org/s/article/The-Case-for-a-Green-and-Just-Recovery?language=en_US (accessed on 25 March 2021).

84. Bodenheimer, M.; Leidenberger, J. COVID-19 as a window of opportunity for sustainability transitions? Narratives and communication strategies beyond the pandemic. Sustain. Sci. Pract. Policy 2020, 16, 61-66.

85. Tukker, A.; Emmert, S.; Charter, M.; Vezzoli, C.; Sto, E.; Munch Andersen, M.; Geerken, T.; Tischner, U.; Lahlou, S. Fostering change to sustainable consumption and production: An evidence based view. J. Clean. Prod. 2008, 16, 1218-1225. [CrossRef]

86. Börjeson, L.; Höjer, M.; Dreborg, K.H.; Ekvall, T.; Finnveden, G. Scenario types and techniques: Towards a user's guide. Futures 2006, 38, 723-739. [CrossRef]

87. Vergragt, P.J.; Quist, J. Backcasting for sustainability: Introduction to the special issue. Technol. Forecast. Soc. Chang. 2011, 78, 747-755. [CrossRef]

88. Intergovernmental Panel on Climate Change (IPCC). Special Report Emissions Scenarios Special Report Working Group III Intergovernmental Panel Climate Change. 2000. Available online: https://www.cambridge.org/jp/academic/subjects/earthand-environmental-science/climatology-and-climate-change/special-report-emissions-scenarios-special-report-workinggroup-iii-intergovernmental-panel-climate-change?format=PB\&isbn=9780521804936 (accessed on 25 March 2021).

89. Riahi, K.; van Vuuren, D.P.; Kriegler, E.; Edmonds, J.; O’Neill, B.C.; Fujimori, S.; Bauer, N.; Calvin, K.; Dellink, R.; Fricko, O.; et al. The Shared Socioeconomic Pathways and their energy, land use, and greenhouse gas emissions implications: An overview. Glob. Environ. Chang. 2017, 42, 153-168. [CrossRef]

90. Van Vuuren, D.P.; Riahi, K.; Moss, R.; Edmonds, J.; Thomson, A.; Nakicenovic, N. A proposal for a new scenario framework to support research and assessment in different climate research communities. Glob. Environ. Chang. 2012, 22, 21-35. [CrossRef]

91. O'Neill, B.C.; Kriegler, E.; Riahi, K.; Ebi, K.L.; Hallegatte, S.; Carter, T.R. A new scenario framework for climate change research: The concept of shared socioeconomic pathways. Clim. Chang. 2014, 122, 387-400. [CrossRef]

92. International Energy Agency (IEA). World Energy Outlook. 2020. Available online: https://www.iea.org/reports/world-energyoutlook-2020 (accessed on 1 April 2021).

93. UK Committee on Climate Change. Net Zero Technical Report. 2019. Available online: https://www.theccc.org.uk/publication/ net-zero-technical-report/ (accessed on 1 April 2021).

94. Kawakami, T.; Kuriyama, A.; Arino, Y. A Net-Zero World-2050 Japan—Insight into Essential Changes for a Sustainable Future: Hayama; Institute for Global Environmental Strategies: Kanagawa, Japan, 2020.

95. Mont, O.; Neuvonen, A.; Lähteenoja, S. Sustainable lifestyles 2050: Stakeholder visions, emerging practices and future research. J. Clean. Prod. 2014, 63, 24-32. [CrossRef]

96. Kishita, Y.; Kuroyama, S.; Matsumoto, M.; Kojima, M.; Umeda, Y. Designing Future Visions of Sustainable Consumption and Production in Southeast Asia. Procedia CIRP 2018, 69, 66-71. [CrossRef]

97. Mao, C.; Koide, R.; Akenji, L. Applying foresight to policy design for a long-term transition to sustainable lifestyles. Sustainability 2020, 12, 6200. [CrossRef] 
98. Watabe, A.; Gilby, S. To see a world in a grain of sand-the transformative potential of small community actions. Sustainability 2020, 12, 7404. [CrossRef]

99. Liu, C.; Nguyen, T.T. Evaluation of Household Food Waste Generation in Hanoi and Policy Implications towards SDGs Target 12. Sustainability 2020, 12, 6565. Available online: https:/ / www.mdpi.com/2071-1050/12/16/6565 (accessed on 15 April 2021).

100. Khodke, A.; Watabe, A.; Mehdi, N. Implementation of Accelerated Policy-Driven Sustainability Transitions: Case of Bharat Stage 4 to 6 Leapfrogs in India. Sustainability 2021, 13, 4339. Available online: https:/ /www.mdpi.com/2071-1050/13/8/4339 (accessed on 15 April 2021). [CrossRef]

101. Organisation for Economic Co-operation and Development (OECD). Building Capacity for Evidence-Informed Policy-Making Lessons from Country Experiences. Available online: https://www.oecd-ilibrary.org/governance/building-capacity-forevidence-informed-policy-making_86331250-en (accessed on 1 April 2021).

102. Cairney, P. The Politics of Evidence-Based Policy Making; Palgrave Macmillan: London, UK, 2016.

103. Kano, H.; Hayashi, T.I. A framework for implementing evidence in policymaking: Perspectives and phases of evidence evaluation in the science-policy interaction. Environ. Sci. Policy 2021, 116, 86-95. [CrossRef]

104. Tsurumi, T.; Yamaguchi, R.; Kagohashi, K.; Managi, S. Attachment to material goods and subjective well-being: Evidence from life satisfaction in rural areas in Vietnam. Sustainability 2020, 12, 9913. [CrossRef]

105. Piao, X.; Ma, X.; Zhang, C.; Managi, S. Impact of Gaps in the Educational Levels between Married Partners on Health and a Sustainable Lifestyle: Evidence from 32 Countries. Sustainability 2021, 12, 4623. [CrossRef]

106. Wang, C.; Ghadimi, P.; Lim, M.K.; Tseng, M.L. A literature review of sustainable consumption and production: A comparative analysis in developed and developing economies. J. Clean. Prod. 2019, 206, 741-754. [CrossRef]

107. Koide, R.; Hotta, Y.; Watabe, A. EBPM towards Lifestyle Innovation. Rev. Environ. Econ. Policy Stud. 2020, 13, 70-73. 